Aksiologiya: Jurnal Pengabdian Kepada Masyarakat

Vol.5, No. 1, Februari 2021 Hal 104 - 111

ISSN 2528-4967 (print) dan ISSN 2548-219X (online)

\title{
Peningkatan Ketrampilan Siswa dalam Menghadapi Perkembangan Keilmuan Geografi Era 4.0 Melalui Pengenalan Drone Mapping
}

\author{
Danardono $^{1}$; M. Iqbal. T. Sunariya ${ }^{1}$; Vidya Nahdiyatul Fikriyah ${ }^{1}$ \\ ${ }^{1}$ Fakultas Geografi, Universitas Muhammadiyah Surakarta \\ Email : danardono@ums.ac.id
}

\begin{abstract}
ABSTRAK
Munculnya era baru revolusi industri 4.0, menuntut tiap bidang keilmuan memiliki perkembangan teknologi yang tinggi, mutakhir, mudah diakses, dan berbasis internet. Tuntutan era baru ini juga mengharuskan bidang keilmuan geografi semakin berkembang menyesuaikan zaman. Perkembangan teknologi di bidang geografi yang saat ini berkembang sebagai bentuk tuntutan era revolusi 4.0 yaitu teknologi drone. Teknologi drone atau yang dikenal dengan pesawat tanpa awak dapat dimanfaatkan untuk pengambilan data dasar dalam kajian-kajian geografi. Di sisi lain, perkembangan teknologi ini belum terintegrasikan dengan silabus pendidikan pada tingkat pendidikan menegah sehingga pembelajaran geografi di tingkat ini cenderung masih bersifat teoretis dan kurang aplikatif. Padahal tuntutan kebutuhan seorang pembelajar geografi harus paham dan mengerti mengenai perkembangan teknologi ini. Adanya kegiatan sosialisasi dan pelatihan mengenai perkembangan teknologi di bidang geografi utama teknologi drone dapat menginisiasi diintegrasikannya pengetahuan mengenai perkembangan teknologi utamanya drone dalam pembelajaran di tingkat menengah. Hal ini nantinya dapat digunakan untuk memicu perubahan sistem pembelajaran geografi di tingkat menengah yang bersifat teoretis menjadi lebih aplikatif. Selain itu, lulusan atau produk dari tingkat menengah dapat memiliki kompetensi dan ketrampilan yang sesuai dengan tuntutan era revolusi industri 4.0 utamanya pada bidang kajian geografi.
\end{abstract}

Kata Kunci: Geografi; Teknologi Drone; Pembelajaran; Revolusi 4.0.

\section{Improving Student Skills in Facing Geographic Scientific Development in Era 4.0 through the Introduction of Drone Mapping}

ABSTRACT

The emergence of a new era of the industrial revolution 4.0 requires each scientific field to have high technological development, easily accessible, and internet-based. The demand of this new era also requires that the field of geographic science developed according to the times. The development of technology in the field of geography which is currently developing as a form of the demands of the revolution era 4.0 is the drone technology. Drone technology, known as drone aircraft, can be used to collect basic data in geography studies. On the other hand, the development of this technology has not been integrated with the syllabus of education at the mid-level education so that geography learning at this level tends to be theoretical and less applicable. Though the demands of the needs of a geography learner must understand and understand about this technological development. The existence of socialization activities and training on technological developments in the main geographic fields of drone technology can initiate the integration of knowledge about the development of technology, especially drones in learning at the secondary level. This can later be used to trigger changes in geographic learning systems at the secondary level that are theoretical to be more applicable. In addition, graduates or products from the middle level can have competencies 
and skills that are in accordance with the demands of the industrial revolution era 4.0, especially in the field of geography studies.

Keywords: Drone Mapping; Geography; DroneLearning System; Revolution 4.0.

\section{PENDAHULUAN}

Kemajuan bidang keilmuan geografi pada era revolusi industri menunjukkan perkembangan yang pesat. Salah satu teknologi yang berkembang dengan pesat yaitu teknologi di bidang penginderaan jauh dan fotogrametri. Saat ini, seseorang dimungkinkan untuk dapat menghasilkan data penginderaan jauh berupa pemotretan udara dengan format kecil secara mandiri. Teknologi yang digunakan berupa teknologi drone atau unmanned aerial vehicle (UAV). Teknologi drone atau UAV dapat didefinisikan sebagai pesawat udara atau suatu wahana dalam penginderaan jauh yang mampu terbang tanpa awak dan dapat dikendalikan dengan jarak yang jauh menggunakan remote control (Casagrande, Sik, \& Szabo, 2018; Garret\&Anderson, 2018; Suroso,n.d.) Jenis-jenis teknologi drone atau UAV sangat beragam dari yang berukuran mikro atau dikenal microdrone sampai yang berukuran sangat besar dengan berbagai macam pemanfaatan dari untuk kegiatan militer sampai untuk kegiatan fotografi dan permainan (Custers, 2016).

Dalam bidang kajian geografi, teknologi drone ini lambat laun mulai menggeser aktivitas pemotretan udara yang tergolong cukup mahal dengan wahana pesawat awak. Kemampuan teknologi drone dalam menghasilkan data foto udara dengan kedetailan tinggi dan real-time menjadikan teknologi ini juga mulai menggeser peran produk penginderaan jauh fotografi lainnya (Suciani \& Rahmadi, 2019; Utomo, 2017). Saatini, teknologi drone dapat menghasilkan foto udara dalam hitungan menit dengan tingkat kedetailan dan keakuratan data tinggi sehingga sangat cocok dimanfaatkan untuk berbagai kajian geografi (Shofiyanti, 2011; Wulan, Ambarwulan, Putra, Ibrahim, \& Putra, 2017). Oleh karena itu, hingga saat ini teknologi drone atau UAV sudah menghasilkan ratusan foto udara dengan berbagai ukuran dan luasan area yang dikaji untuk berbagai kajian di bidang geografi seperti kajian pemetaan tanah (Hartono \& Darmawan, 2018), hidrologi, geomorfologi, kebencanaan, sosial, dan budaya (Marfai, Rosaji, Cahyadi, \& Ghozali, 2014). Peran teknologi drone dalam berbagai bidang kajian geografi menjadikan ketrampilan pengoperasian drone menjadi hal wajib bagi seluruh geograf dan pembelajar bidang geografi. Ketrampilan dalam pengoperasian teknologi drone menjadi hal mutlak yang harus diajarkan dan diberikan kepada pembelajar yang mempelajari kajian bidang geografi.

Disisi lain, teknologi drone sendiri masih tergolong baru di Indonesia dan belum banyak dikenal dan dimanfaatkan oleh masyarakat luas. Bahkan, pada beberapa tingkat 
pendidikan menengah belum banyak dikenal dan diajarkan. Pembelajaran di tingkat pendidikan menengah masih hanya sebatas mengenai teori di bidang keilmuan geografi dan minim mempelajari keilmuan geografi secara aplikatif. Pemahaman mengenai aplikasi geografi utamanya teknologi drone masih belum dintegrasikan ke dalam pembelajaran karena kurangnya updating materi dan sumberdaya yang dapat dimanfaatkan oleh guru dalam pembelajaran.

Padahal apabila mengacu pada kurikulumterbaruditingkatpendidikan menengah, terdapat tiga kompetensi yang harus dimiliki oleh pembelajar atau siswa yaitu kompetensi kognitif, kompetensi afektif, dan kompetensi psikomotorik. Kompetensi psikomotorik merupakan kompetensi yang berkaitan dengan ketrampilan langsung yang dapat diaplikasikan dalam membantu kompetensi kognitif (teori keilmuan). Kompetensi psikomotorik dalam bidang geografi salah satunya berupa kemampuan dalam pengoperasian drone untuk mendukung pengembangan keilmuan sistem informasi geografis. Oleh karena itu, pemahaman mengenai teknik pengoperasian drone sangat penting dimiliki untuk mendukung pencapaian kompetensi pembelajar geografi di tingkat pendidikan menengah.

Masihkurangnyapengetahuandan pemahaman mengenai perkembangan teknologi di bidang geografi pada tingkat pendidikan menengah dapat diatasi dengan melakukan kegiatan sosialisasi dan pelatihan langsung kepada siswa dan guru di Madrasah Aliyah Negeri 3 Bantul. Maksud kegiatan ini dilakukan untuk mendukung terlaksananya capaian kompetensi pembelajaran di tingkat pendidikan menengah khususnya pada minat IPS dalam ranah pemahaman perkembangan teknologi mutakhir di bidang kegeografian. Tujuan dari kegiatan ini yaitu (1) Meningkatkan pemahaman siswa dan guru geografi mengenai perkembangan teknologi di bidang keilmuan geografi utamanya pemanfaatan teknologi drone dalam pembelajaran geografi (2) Memberikan demontrasi cara menggunakan teknologi drone dan pemanfaatannya dalam pembelajaran geografi.

\section{METODE PENELITIAN}

Metode pelaksanaan kegiatan adalah sosialisasi dan pelatihan dengan bentuk diskusi dan tanya jawab yang berisi mengenai pengenalan dasardasar drone mapping dan aplikasinya dalam bidang geografi. Pelaksanaan kegiatan dibagi menjadi tiga bagian yaitu (1) pra-kegiatan; (2) pelaksanaan kegiatan; dan(3)evaluasikegiatan.Prakegiatan terbagi menjadi dua kegiatan besar yaitu perijinan dan koordinasi awal dengan pihak sekolah mengenai kegiatan; serta penyusunan materi dan modul kegiatan. Pelaksanaan kegiatan dilakukan dengan metode sosialisasi melalui kegiatan ceramah di ruangan dan demontrasi langsung dengan mengoperasikan drone di lapangan. Foto kegiatan ceramah di ruangan tentang teknologi drone mapping dapat dilihat pada Gambar 1. 


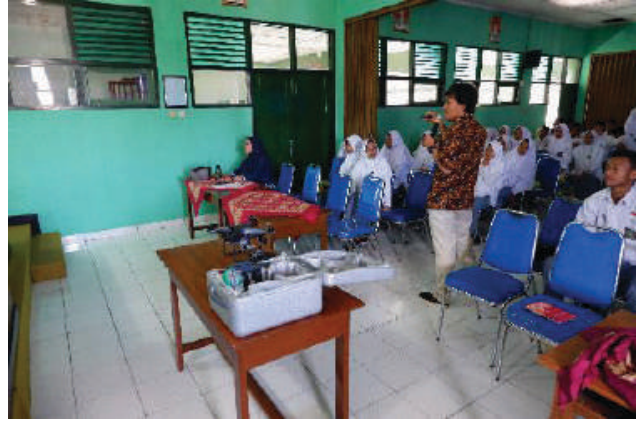

Gambar 1: Pelaksanaan Ceramah tentang Teknologi Drone Mapping

Tahap terakhir yaitu evaluasi kegiatan dilakukan dengan meminta saran, masukan, dan testimoni kepada peserta mengenai kegiatan. Berdasarkan saran, masukan, dan testimoni ini akan digunakan sebagai bahan perbaikan kegiatan lanjutan di tempat-atat sekolah lain. Pelaksanaan kegiatan evaluasi dilakukan pada akhir sesi ceramah dan diskusi di ruangan yang terlihat pada Gambar 2 .

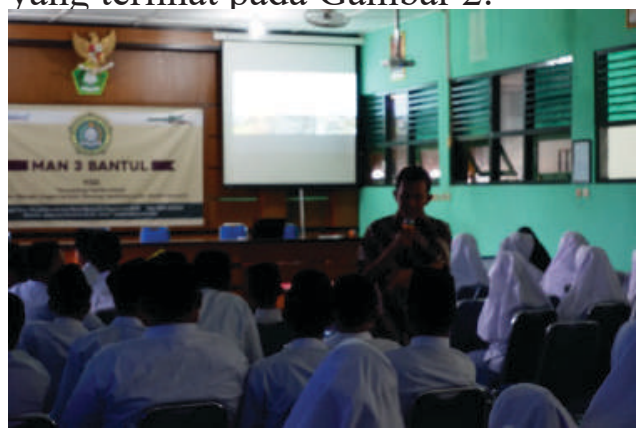

Gambar 2: Penyampaian Saran dan

Testimoni Siswa

Secara lebih sederhana runtutan atau alur metode pelaksanaan tersaji pada diagram alir penelitian di Gambar 3.

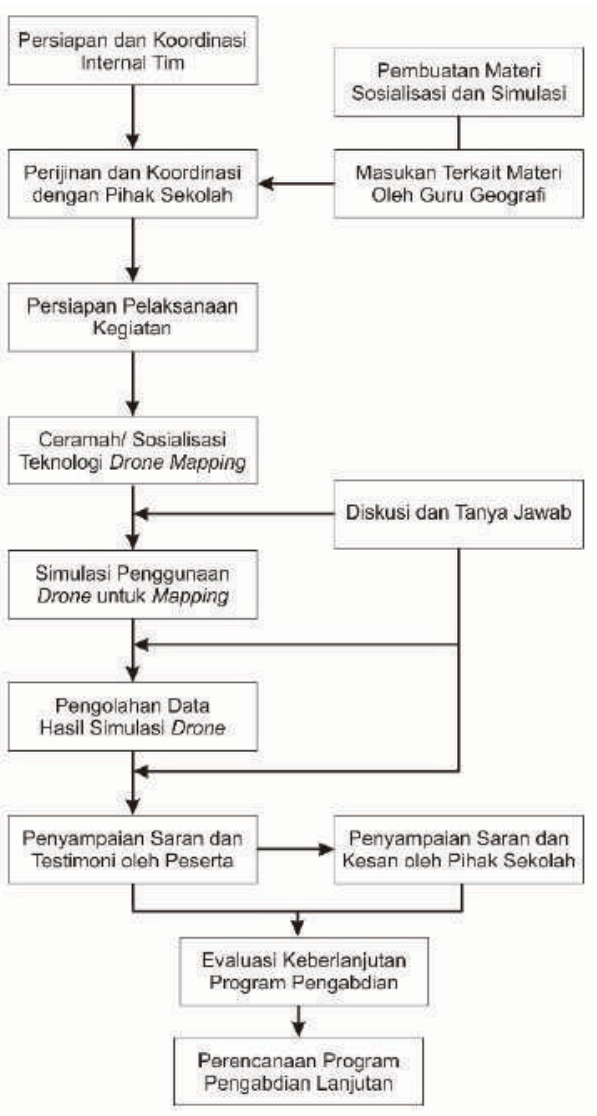

Gambar 3: Diagram Alir Penelitian

Materi yang akan disampaikan pada kegiatan pengabdian ini diawali dengan pengenalan perkembangan teknologi dan tantangan bidang keilmuan geografi di era revolusi industri. Selanjutnya dikenalkan salah satu teknologi yang berkembang di geografi saat ini yaitu teknologi drone-atat unmanned aerial vehicle. Selanjutnya dikenalkan mengenai komponen-komponen dari teknologi drone. Setelah itu, disampaikan mengenai cara pengoperasian teknologi drone. Materi mengenai pengoperasian drone dilakukan dengan penyampaian di kelas dan demontrasi langsung. Terakhir disampaikan mengenai terapan atau pemanfaatan hasil pemotretan udara dengan teknologi drone dalam bidang 
keilmuan geografi.

Peserta kegiatan pengabdian ini yaitu seluruh siswa kelas penjurusan IPS dan guru geografi di Madrasah Aliyah Negeri 3 Bantul. Siswa kelas penjurusan IPS dipilih mengingat mata pelajaran geografi di tingkat SMA hanya dipelajari pada kelas penjurusan IPS. Masih rendahnya pemahaman siswa kelas penjurusan IPS mengenai perkembangan teknologi drone dalam bidang geografi menjadi fokus atau muara dari kegiatan pengabdian ini. Adanya kegiatan ini diharapkan dapat meningkatkan pemahaman siswa kelas penjurusan IPS dan guru geografi di MAN 3 Bantul mengenai perkembangan teknologi di bidang geografi. Kegiatan ini dilaksanakan pada Bulan Agustus 2019 yang bertempat di Aula MAN 3 Bantul.

\section{HASIL DAN PEMBAHASAN}

Kegiatan pengabdian masyarakat ini dilaksanakan pada hari Selasa; 6 Agustus 2019 bertempat di Aula Madrasah Aliyah Negeri 3 Bantul. Peserta dari kegiatan ini berjumlah 50 peserta yang terdiri dari siswa jurusan IPS dan guru mata pelajaran. Siswa yang dipilih merupakan siswa dari jurusan IPS yang mendapatkan mata pelajaran geografi sehingga nantinya hasil dari kegiatan dapat memperdalam dan mempertajam keilmuan terapan geografi bagi siswa dan guru mata pelajaran geografi.

Kegiatan pengabdian masyarakat ini dapat terlaksana dengan beberapa runtutan kegiatan. Kegiatan diawali dengan adanya komunikasi intensif dengan pihak guru mata pelajaran geografi di MAN 3 Bantul mengenai keresahan akan kompetensi yang diajarkan masih hanya sebatas teori dan belum ada yang bersifat aplikatif. Komunikasi ini dilanjutkan dengan permintaan untuk diadakan kegiatan sosialisasi dan pelatihan dasar untuk mengenalkan beberapa terapan praktis bidang geografi. Kegiatan ini kemudian berlanjut dengan mekanisme perijinan kepada pihak sekolah (MAN 3 Bantul) secara resmi untuk mengadakan kegiatan sosialisasi dan pelatihan mengenai "Perkembangan Teknologi Bidang Keilmuan Geografi di Era Revolusi Industri 4.0 Melalui Pengenalan Teknologi Drone Mapping". Pihak sekolah dalam hal ini MAN 3 Bantul sangat mendukung kegiatan tersebut dan memfasilitasi terselenggaranya kegiatan sosialisasi dan pelatihan tersebut. Pelaksanaan perijinan dan koordinasi pra-kegiatan dilaksanakan selama seminggu sebelum kegiatan sosialisasi dan pelatihan dilakukan.

Kegiatan sosialisasi dan pelatihan diawali dengan memberikan penyegaran dan pemahaman mengenai konsep perkembangan teknologi di era revolusi 4.0 dalam lingkup bidang geografi. Selanjutnya, diberikan salah satu contoh bentuk perkembangan teknologi di bidang geografi yang sedang trending saat ini yaitu mengenai pemanfaatan teknologi drone. Sebagai pengantar diberikan pemahaman dasar mengenai serbaserbi drone dan dilanjutkan dengan bentuk-bentuk terapan teknologi drone dalam bidang geografi. Saat pemberian materi, diselipkan beberapa 
waktu untuk kegiatan diskusi atau tanya jawab seputar teknologi drone dan pemanfaatannya. Saat sesi diskusi, peserta terlihat sangat antusias terhadap materi yang diberikan. Hal ini terlihat dari sesi diskusi yang hidup dengan berbagai pertanyaan yang diberikan oleh peserta. Saat sesi diskusi terdapat peserta yang juga memberikan tanggapan terhadap pertanyaan peserta lain yang dapat menggambarkan bahwa materi telah tersampaikan dengan baik kepada peserta. Foto kegiatan saat dilakukan pemberian materi dapat dilihat pada Gambar 4. dan sesi diskusi terlihat pada Gambar 5.

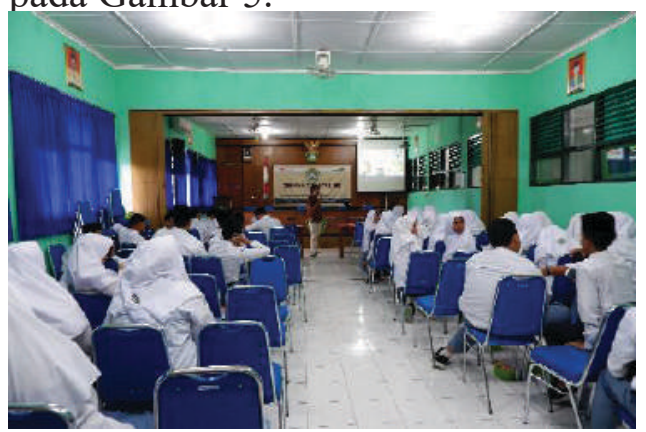

Gambar 4: Kegiatan Sosialisasi Penggunaan Teknologi Drone Mapping

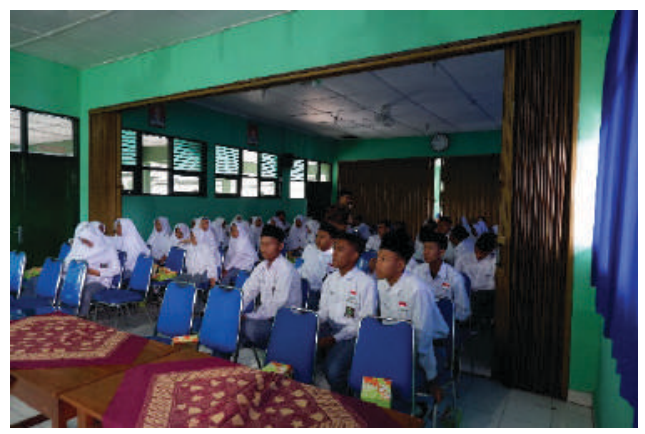

Gambar 5: Sesi Kegiatan Diskusi

Setelah kegiatan sosialisasi dan diskusi dilaksanakan, dilanjutkan dengan kegiatan pelatihan pengoperasian dasar teknologi drone.
Kegiatan ini dilakukan diluar ruangan untuk memberikan kesempatan bagi peserta secara langsung cara mengoperasikan teknologi drone. Pada kegiatan ini dijelaskan secara rinci cara untuk mengoperasikan drone termasuk beberapa hal yang harus dilakukan sebelum drone diterbangkan serta tips-tips dalam mengoperasikan drone. Saat kegiatan ini peserta terlihat lebih antusias dengan banyaknya peserta yang ingin mencobauntukmengoperasikandrone, namun karena keterbatasan waktu hanya ada beberapa peserta saja yang berkesempatan untuk mengoperasikan drone secara langsung. Adapun foto kegiatan pelatihan dapat dilihat pada Gambar 6.

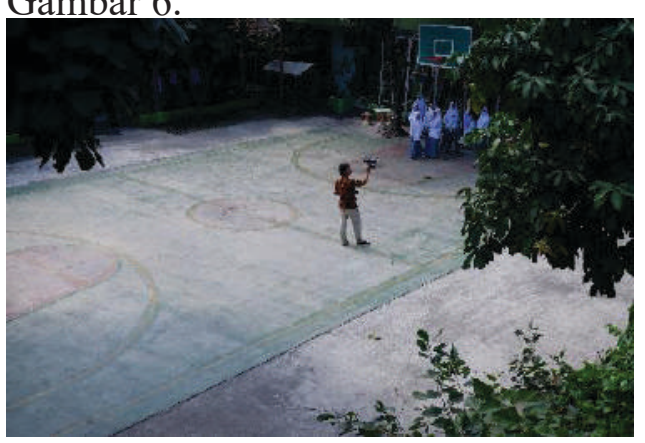

Gambar 6: Kegiatan Pelatihan

Pengoperasian Teknologi Drone

Setelah dilakukan kegiatan simulasi pengoperasian drone di lapangan. Kegiatan selanjutnya yaitu melakukan pemrosesan gambar hasil pemotretan di lapangan. Pemrosesan gambar untuk membuat foto udara sekitar sekolah dilakukan secara bersama-sama dengan menggunakan perangkat komputer. Proses pembuatan foto udara dijelaskan di ruang dengan konsep pemaparan dan diskusi. Contoh hasil pemrosesan foto udara dapat dilihat pada Gambar 7. 


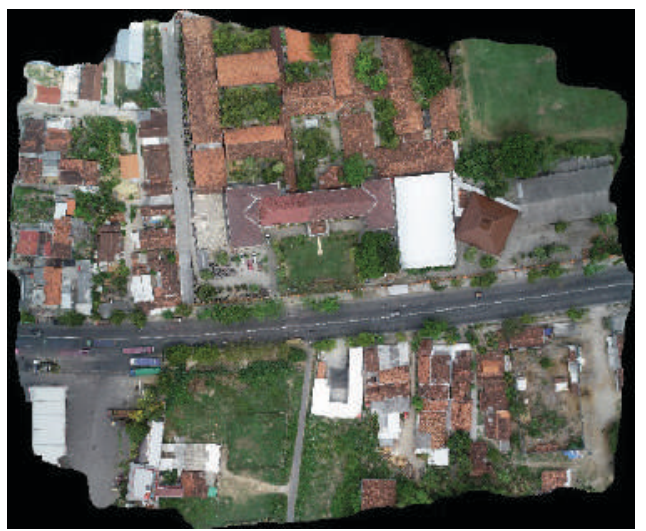

Gambar 7: Contoh Hasil Pemrosesan Foto Udara

Hasil kegiatan sosialisasi dan pelatihan ini mendapat respon dan memberikan manfaat yang baik bagi seluruh siswa dan guru, diantaranya yaitu dengan semakin meningkatnya pengetahuan dan pemahaman siswa dan guru mengenai perkembangan teknologi di bidang geografi serta meningkatkan semangat belajar dalam mata pelajaran geografi dengan adanya bentuk pembelajaran geografi yang lebih interaktif dan aplikatif. Hasil respon dan manfaat ini dapat terlihat dari saran dan testimoni yang diberikan oleh siswa. Sebagian besar siswa mengatakan bahwa kegiatan ini berlangsung menarik dan dikemas dengan metode yang interaktif serta dapat memberikan pemahaman kepada siswa bahwa kajian geografi itu luas dan menarik. Sementara, dari guru dan pihak sekolah memberikan ucapan banyak terima kasih atas kegiatan yang telah dilaksanakan dan adanya harapan untuk melaksanakan kegiatan lanjutan dengan tema yang lebih spesifik yaitu fokus pada salah satu terapan teknologi drone dalam bidang kajian geografi.
Selain manfaat yang dihasilkan dari kegiatan, keberlanjutan dari sosialisasi dan pelatihan ini berupa terjalinnya hubungan kemitraan untuk berperan dalam meningkatkan kompetensi pembelajaran geografi di tingkat pendidikan menengah. Sebagai tindak lanjut, kegiatan serupa dapat dilakukan dengan mengangkat tema yang lebih spesifik mengenai terapan teknologi drone dalam salah satu bidang kajian geografi. Hal ini dimaksudkan untuk memberikan pengetahuan lebih komprehensif mengenai kegunaan teknologi drone dalam menunjang peningkatan kompetensi siswa dan guru mengenai perkembangan teknologi drone. Selain itu, kegiatan ini juga diharapkan dapat memicu perubahan sistem pembelajaran pada mata pelajaran geografi yang lebih aplikatif di tingkat pendidikan menengah.

\section{SIMPULAN}

Perkembangan teknologi di era revolusi 4.0 menuntut pembelajar geografi di tingkat sekolah menengah memiliki ketrampilan dalam bidang teknologi salah satunya pengoperasian drone untuk keperluan pemetaan. Adanya kegiatan sosialisasi pengenalan teknologi drone di madrasah aliyah dapat memberikan pengetahuan dasar mengenai pengoperasian teknologi drone untuk pengembangan ketrampilan bidang geografi. Selain itu, adanya kegiatan simulasi pemetaan dengan drone dapat menambah ketrampilan pembelajar atau siswa dalam mengoperasikan teknologi drone ini. Respon siswa 
setelah kegiatan sosialisasi dan simulasi yaitu sangat antusias untuk mengetahui lebih lanjut mengenai teknologi drone. Hal ini terlihat dari banyaknya pertanyaan yang diajukan ketika sesi diskusi dan banyaknya siswa yang ingin mencoba untuk menerbangkan drone saat simulasi.

\section{DAFTAR PUSTAKA}

Casagrande, G., Sik, A., \& Szabo, G. (2018). Small Flying Drones. Netherlands: Springer International Publishing.

Custers, B. (2016). The Future of Drone Use: Opportunities and Threats from Ethical and Legal Perspectives. Netherlands: Springer International Publishing.

Garret, B., \& Anderson, K. (2018). Drone Methodologies: Taking Flight in Human and Physical Geography. Transactions of the Institute of British Geographers, 43(3), 341-359.

Hartono, D., \& Darmawan, S. (2018). Pemanfaatan Unmanned Aerial Vehicle(UAV) Jenis Quadcopter untuk Percepatan Pemetaan Bidang Tanah. Reka Geomatika, 2018(1), 30-40.

Marfai, M.A., Rosaji, F. S. C., Cahyadi, A., \& Ghozali, M. R. (2014). Analisis Dinamika Pantai di Teluk Baron Menggunakan Teknologi Pesawat Tanpa Awak. Prosiding PekanIlmiah Tahunan Ikatan Geograf Indonesia (PIT IGI) 2014.

Shofiyanti, R. (2011). Teknologi Pesawat Tanpa Awak untuk Pemetaan dan Pemantauan Tanaman dan Lahan Pertanian. Informatika Pertanian, 20(2), 58-64.

Suciani, A., \& Rahmadi, M. T. (2019). Pemanfaatan Drone DJI Phantom 4 untuk Identifikasi
Batas Administrasi Wilayah. Jurnal Geografi, 11(2), 218223. https://doi.org/10.24114/ jg.v11i2.10604

Suroso, I. (n.d.). Peran Drone atau Unmanned Aerial Vehicle (UAV) Buatan STTKD dalam Dunia Penerbangan. Jakarta.

Utomo, B. (2017). Drone untuk Percepatan Pemetaan Bidang Tanah. Media Komunikasi Geografi, 18(2), 146-155.

Wulan, T. R., Ambarwulan, W., Putra, A. S., Ibrahim, F., \& Putra, M. D. (2017). Pemetaan Cepat Kawasan Terdampak Bencana LongsordanBanjirdi Kabupaten Bangli , Provinsi Bali. Majalah Geografi Indonesia, 31(2), 4451. 